Www.ijbpas.com

\title{
INTEGRATIVE APPROACH TO MANAGE DUSHTVRANA IN CHRONIC ANAEMIC PATIENT
}

\section{THORAT KP ${ }^{1}$, KHANDARE $\mathrm{S}^{2}$ AND KULLOLLI $\mathrm{V}^{3 *}$}

1: Associate Professor \& PhD Scholar, Dept. of Roga Nidana, Parul Institute of Ayurved and Research, Parul University

2: Professor, Dept. of Shalya Tantra, Parul Institute of Ayurved, Parul University 3: Professor \& Guide PhD, Dept. of Roga Nidana, Parul Institute of Ayurved, Parul University

*Corresponding Author: Khandare S; E Mail: sunil.khandare260000@paruluniversity.ac.in

Received $12^{\text {th }}$ Dec. 2021; Revised $14^{\text {th }}$ Jan. 2022; Accepted $7^{\text {th }}$ Feb. 2022; Available online $5^{\text {th }}$ March 2022 https://doi.org/10.31032/IJBPAS/2022/11.3.1076

\begin{abstract}
The remedy and recuperation of Wounds are a number of the oldest subjects discussed within the scientific Literature. Information of Wound recovery permits Surgeons to manipulate wounds to obtain most appropriate consequences in a short length. In Ayurveda non- healing ulcer may be correlated with Dushta Vrana. On other hand a lot of comorbidities additionally impact the healing e.g., Anaemia, Diabetes Mellitus and so on. Chronic anaemia and DM happen to be obstacle for wound healing unless they are corrected systemically. The systemic correction of the duo requires either intensive and costlier invasive therapies or long term traditional therapies. This study was planned to assess the alternative measure to bypass both the costlier and time- consuming measures in non- healing ulcer management. Kshara Karma (Alkali Therapy) for Shodhana and Ropana of Dushta Vrana is most important procedure among Sixty upakramas meant for Vrana, in conjunction with collagen granules for quicker epithelilization. Kshar has chhedana (excision), Bhedana (incision), and Lekhana (scrapping) properties along with Tridoshhara karma(equilibrium of Vata, Pitta, Kapha). Collagen is an essential constructing brick of the pores and skin. After application as an adjunctive wound therapy, stimulates and recruit immune cells and fibroblasts and martyrs itself for degradation by way of MMPs, thereby keeping local ECM shape and selling healing ${ }^{1}$.
\end{abstract}


A case document of a patient having open traumatic ulcer with chronic Anaemia, DM, HTN, that healed with application of Apamarga Kshara and collagen particles as an integrative approach is presented here in.

\section{Keywords: Chronic anaemia, Pandu Roga, Dustha Vrana, Collagen Granules, Kshara, Kshara karma}

\section{INTRODUCTION:}

Vrana is visible as debilitating and scaring disease normally seen affecting the individual at any age. Vrana is because of Dhatu Naasha (destruction of tissue), and characterized by Vedana (pain), Srava (discharge), and Vikriti (deformity). Acharya Sushruta has described Shastiupakramas (60 tactics) for management of Wound $^{2}$, to acquire appropriate approximation, early recuperation and proper scar. Amongst Shasthi Upakarama, Kshar karma, which is non-invasive procedure, without any complications, does the shodhana of Dushta Vrana. It eliminates all slough/dead tissue and yield Shuddha vrana, thus complements wound healing. Thus, Apamarga Kshar with collagen granules selected for the management of of Dushta Vrana.

The real and potential problem of wound healing in this patient was the coexistence of co- morbid conditions like, chronic anaemia, diabetes mellitus and the hypertension. The aim of the study was to observe the healing of the wound by local wound care within the shortest period that may be possible, overcoming the interference of the chronic anaemia, diabetes mellitus and hypertension.

\section{Case Report:}

Single case observational study

\section{Study Centre:}

Parul Ayurved Hospital, Limda, Vadodara, Gujarat

A 57-year-old male patient presented with complaint of traumatic ulcer on right hand near thumb associated with pain, foul smelling discharge and inflamed, that was non -responsive to treatment for 2 months, treated elsewhere.

Before two months, the patient suffered with an accident while going on bike, he was hit by a sharp stone, resulting in wound with the swelling and pain on his right hand at web space between the Thumb and the Index finger. Wound got infected due to improper care and compromised immunity probably due to the chronic anaemia and the diabetes mellitus. Foul smelling pus and slough further hampered the wound healing. The wound was treated with antibiotics ointment by a local doctor but it failed to respond. The 
patient also went to some other hospitals for treatment but it did not react positively to the treatment (though details of such treatment are not available with the patient). At last, he came for management Parul Ayurved hospital, Limda, Vadodara, Gujarat.

Patient was known case of chronic anaemia, Hypertension, Diabetes Mellitus with long standing bleeding piles (Haemorrhoids).

On General/ Systemic Examination:

Patient was Conscious and Oriented, walked on his own into Shalya OPD.

Pallor ++

Conjunctiva Pale

RS- B/L AE+, Clear

P/A- Soft, Non-tender

CNS: NAD

CVS: S1S2

BP- $160 / 90$ on regular medication

Pulse- $87 / \mathrm{min}$

Spo2- $98 \%$ on RA

GC- Stable

Local examination: Ulcer was seen on right hand near thumb and index finger web space, measuring about $3 \times 2 \times 0.5 \mathrm{cms}$ in dimension with profuse purulent discharge and irregular margins; edges were inflamed. The floor was unhealthy covered with slough, and unpleasant intolerable smell was present.

Tenderness was also present with surrounding induration and local rise in temperature. Local lymph nodes were not involved.

Patient was having anaemia (probably secondary to chronic first degree Haemorrhoids) having symptoms of Vataja Pandu i.e Ruja (pain), Angtoda (Malaise) Kampa (tremors), Anaha (Flatulence), Balakshaya (weakness), Rooksha Shira (weaker pulse), Gatra ruk (pain at the inflammatory site), Ruksha tvaka (dryness of skin and mucosa).

Investigations: the investigations confirmed the clinical Pandu as the anaemia secondary to the bleeding piles. The subnormal haemoglobin percentage (8.2 gm/dl) and Total Erythrocyte count and variation in the blood indices like decreased P.C.V, M.C.V and M.C.H.C indicating anaemia of both nutritional and haemorrhagic aetiologies. The random blood sugar levels and the urine sugar levels were indicative of the existing diabetes mellitus.

Investigation: 


\begin{tabular}{|c|c|c|c|}
\hline & $\begin{array}{c}\text { PARUL AYURVED HOSPITAL } \\
\text { Teaching Hospital of Parul Institute Of Ayurved } \\
\text { Parul University Limda, Vadodara, Gujarat } 391760\end{array}$ & & \\
\hline $\begin{array}{l}\text { Patient's Name } \\
\text { Referred by } \\
\text { Date } \\
\text { Hospital No }\end{array}$ & $\begin{array}{l}\text { : Anand Goyal } \\
: \text { Dr. Vivekangnd Kullolli } \\
: \text { 26/12/2021 02:46 } \\
:\end{array}$ & $\begin{array}{l}\text { Ref. No. } \\
\text { Age } \\
\text { Sex } \\
\text { IPD }\end{array}$ & $\begin{array}{l}: 22002770 \\
: 57 \text { Years } \\
: \text { Male } \\
:\end{array}$ \\
\hline
\end{tabular}

HEMOGRAM

\begin{tabular}{|c|c|c|c|}
\hline Test Name. & Result & Units & Biological Reference Interval \\
\hline „Hemoglobin: & 8.2 & $g / d l$ & {$[13.0-18.0]$} \\
\hline Total RBC Count : & 3.16 & $\mathrm{mill} / \mathrm{cmm}$ & {$[4.7-6.0]$} \\
\hline \multicolumn{4}{|l|}{ Blood Indices } \\
\hline P.C.V: & 36.8 & $\$$ & {$[42-52]$} \\
\hline M.C.V.: & 56.36 & femtolitre & [78-100] \\
\hline M.C.H.: & 26.56 & $\mathrm{pg}$ & {$[27-31]$} \\
\hline M.C.H.C.: & 23.8 & $g / d$ & {$[32-36]$} \\
\hline R.D.W.: & 14.4 & $\$$ & {$[11.5-14.0]$} \\
\hline Total WBC Count : & 7200 & $1 \mathrm{cmm}$ & {$[4000-10000]$} \\
\hline \multicolumn{4}{|c|}{ Differential WBC Count } \\
\hline Polymorphs: & 52 & 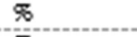 & {$[60-70]$} \\
\hline Lymphocytes: & 45 & $\$$ & {$[20-40]$} \\
\hline Eosinophils: & 2 & $\$$ & {$[1-4]$} \\
\hline Monocytes: & 1 & $\$$ & {$[2-6]$} \\
\hline Bosophils: & 00 & $\mathbb{D}$ & {$[0-1]$} \\
\hline Platelet Count : & 347000 & $/ \mathrm{cmm}$ & $150000-450000$ \\
\hline
\end{tabular}

ERYTHROCYTE SEDIMENTATION RATE (ESR)

\begin{tabular}{|c|c|c|c|}
\hline Test Name & Result & Units & Biological Reference Interval \\
\hline After 1 hour: & 16 & $\mathrm{~mm}$ & {$[\mathrm{M}: 1-7 / \mathrm{F}: 3-12]$} \\
\hline
\end{tabular}

\section{Signature.}

PARUL AYURVED HOSPITAL

Teaching Hospital of Parul Institute Of Ayurved Parul University Limda, Vadodara, Gujar at-391760

\begin{tabular}{llll}
\hline Patient's Name & : Anand Goyal & & \\
Referred by & $:$ Dr. Vivekanand Kullolli & Ref. No. & $: 22002770$ \\
Date & $: 26 / 12 / 2021 \quad 02: 46$ & Age & $: 57$ Years \\
Hospital No & $:$ & Sex & $:$ Male \\
\hline
\end{tabular}

\section{BIOCHEMICALTESIS}

\begin{tabular}{llll}
\hline Test Name & Result & Units & Biological Reference Interval \\
\hline & & & \\
Random Blood Sugar : & 212 & $\mathrm{mg} / \mathrm{dl}$ & $70-140$ \\
Uric Acid : & 9.4 & $\mathrm{mill} / \mathrm{cmm}$ & $3.4-7.0$
\end{tabular}

Signature. 


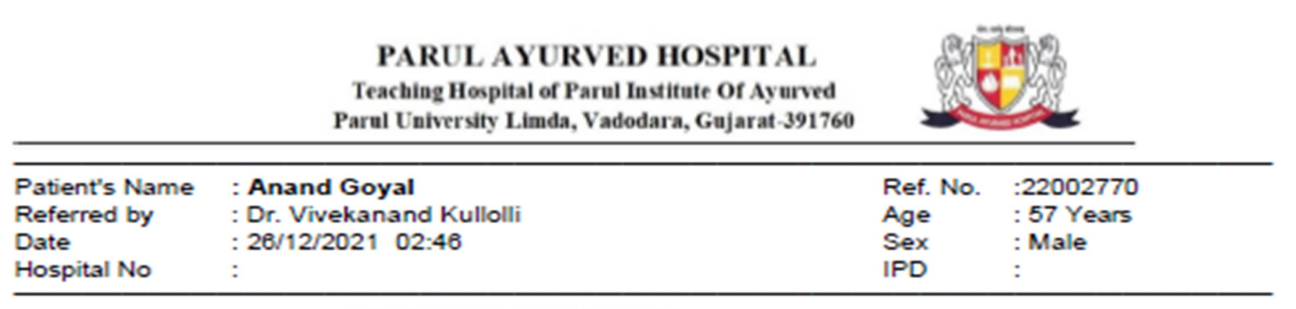

\section{URINEEXAMINATION}

PHYSICAL EXAMINAIION

Volume

Color

Blood

Appearance

Deposite

CHEMICAL EXAMINATION

Sp. Gravity

Protein

Glucose

Ketone

Urobilinogens

Bile Salts

Bile Pigment

Reaction

MICROSCOPIC EXAMINATION

Pus cells

Red Cells

Epithilial Cells

Casts

Crystals

Yeast Cells

Trichomonas Vag.

Bacteria
- $-25 \mathrm{ml}$

-Pale yellow

-Absent

- Clear

-Absent

1.021

Absent

$++$

Absent

Absent

Absent

Absent

6.2

[After centrifugation at 2000 r.p.m for 5 minutes]

$-2-3$

Absent /H.P.F

Absent /H.P.F

Absent

Absent

Absent

Absent

Absent

Signature.

\section{MATERIALS AND METHODS}

In this study Apamarga Kshara with collagen granules was used for local application.

Contents of Apamarga Kshar -Apamarga

Kshara

Content of collagen granules: Sterile Collagen Particle

\section{Treatment Plan}

Wound was cleaned with Triphala Kwath (decoction) daily, after proper cleaning with sterile swabs, Apamarga Kshar was locally applied once and dressing was done with sterile gauze.

After that up to three days only Triphla kwath Prakshalan (washing with Triphala decoction) was done and then after dressing with collagen granules and bandaging done once in three days.

Total duration of treatment was 14 days.

\section{RESULTS}

The clinical features of Dushta Vrana were improved by the $3^{\text {rd }}$ day and the wound was healed completely at the end of $2^{\text {nd }}$ week 
leaving minimal scar. (Images of the same patient, taken at regular interval are inserted as below).
Day 1
During a follow up for a period of 1 month, no signs of recurrence were noticed.

inserted as below).

On Arrival (Day 0)
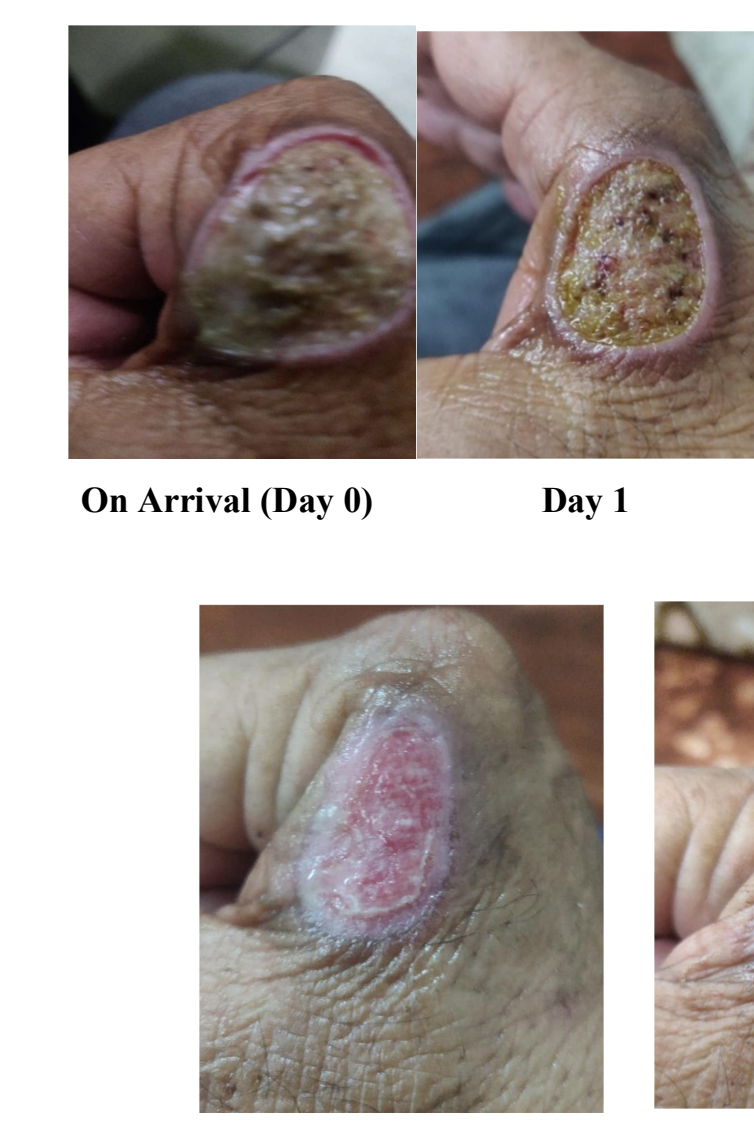

Day 9



Day 12

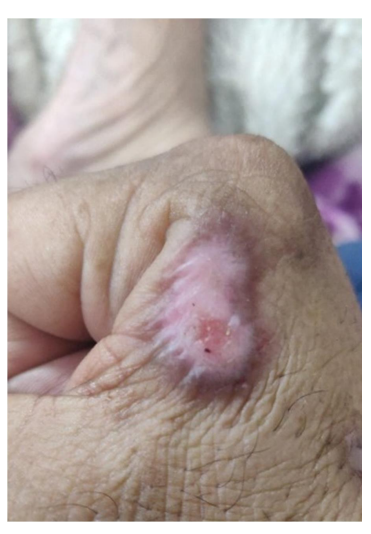

Day 14

\section{DISCUSSION}

\section{Effect on Vrana Vedana (Pain at wound} site):

Pain and tenderness was completely reduced at the end of treatment. Severe pain present at the beginning was completely reduced on $3^{\text {rd }}$ day. Apamarga kshara due to its Ushna virya ${ }^{3}$ could act as Vedanasthapaka (Analgesic) by pacifying Vata.

Effect on Vrana Varna: on $3^{\text {rd }}$ day slough was completely reduced and floor was covered with red, healthy granulation tissue. Laghu (lightness) and Ruksha guna (dryness) are present in Apamarga. Laghu and Ruksha guna have got Lekhana (scrapping) property, due to which slough was removed as well as the wound floor was also cleaned.

\section{Effect on Vrana Srava (Wound} Discharge): Profuse, Purulent discharge was completely reduced at the end of treatment. Purulent discharge present at the beginning was completely reduced on $3^{\text {rd }}$ 
day. This may be due to Shoshana (absorbent) properties present in Apamarga kshara. Wound became free from slough and pus at the end of $3^{\text {rd }}$ day. This is due to Shodhana property of Apamarga kshar.

\section{Effect on Vrana Gandha (Odour of}

Wound): Unpleasant smell present at the beginning of treatment was completely reduced by the end of $3^{\text {rd }}$ day. The Krimighna (Antibacterial), Vishaghna (Detoxification of the bacterial toxins from the wound site), Kushthaghna (correcting capability of disfigurement secondary to wound) properties of Apamarga Kshara, helped to remove the infection and foul smell.

\section{Effect on Vrana Aakriti (Wound Shape} and Size) At the end of the treatment, Vrana completely healed with minimal scar. Apamarga helped to reduce the infection, slough and collagen granules helps to contract wound size by promoting healing and the rate of contraction.

\section{Effect of Pandu on Healing:}



Among various Nidanas mentioned for the causation of Pandu, we can segregate Vataja Pandu Nidanas. Those cause both Vata Pitta Prakopa especially Ruksha and
Laghu Guna of Vata (it is mainly due to the Dhatu kshaya secondary to bleeding through first degree haemorrhoids that the patient is having since long period) and 
Tikshana Ushna Guna of Pitta. The above mentioned Guna of Vata will cause Vishama Agni and will affect the digestion. At the same time Prakupita Pitta (Pachaka Pitta) also contribute to improper digestion and both in turn will hamper the nourishment of Rasa Dathu. This will lead to the irregular nourishment of preceding Dhatu, which in turn lead to Varnakashaya, Ojokshaya and Rasakshaya. All this clearly indicate the involvement of Apatarpana type of pathological sequel in Vataja Pandu. Increase of Gunas such as Ruksha and Laghu as a resultant of Nidana Sevana will cause Dathu Kashaya, Tikshna and Ushna Guna Vriddhi of Pitta will also contribute in Dathu Shoshana as well ${ }^{4}$. All the above mentioned features could be appreciated clinically, also could be correlated and interpreted through Blood Indices of the investigation and the lower Haemoglobin percentage and reduced total red blood cell count of the patient.

Though there is systemic derangement with the patient's nourishment due to chronic anaemia and diabetes mellitus, surprisingly, the wound could to heal within the normal time period after application of Apamarga Kshara followed by collagen granules. This suggests that Kshara and collagen can help the improvement of neo -angiogenesis thus constructing the granulation of the wound, irrespective of the general debility. This case study, if proved even in the larger sample size, will lead to greater revolution in the wound healing with integrated approach.

\section{CONCLUSION:}

On the basis of this case study, it can be concluded that, local application of Apamarga Kshar for chemical debridement as Shodhana karma was found to be very effective in the management of Dushta Vrana along with collagen granules possesses the high efficacy in contraction of wound and epithelialization (Vrana ropana) with fine scaring without producing any adverse effect and relief in signs and symptoms of Dushta Vrana. Even though healing depends on the multiple factors like adequate amount of haemoglobin to nourish tissue, absence of disease like DM, in this case study both chronic anaemia and diabetes mellitus were present. That was the cause for the delayed healing before application of the Kshara and Collagen granules. If this integrative therapy of Kshara application followed by Collagen granules would have not been applied then probably, the systemic correction of the duo would have required either intensive and costlier invasive therapies or long term traditional therapies. This study could prove that an alternative measure to bypass both the costlier and 
time consuming measures in non- healing ulcer, does exists in the form of integrative medicament with Kshara and collagen granules. Thus, it can be used as an integrative approach for management of Dushta Vrana i.e non healing ulcer even in comorbid conditions like Anaemia and Diabetes mellitus.

\section{REFERENCES:}

[1] Kallis PJ, Friedman AJ. Collagen Powder in Wound Healing. J Drugs Dermatol. 2018 Apr 1;17(4):403408. PMID: 29601617.

[2] Sushruta Samhita, Edited with Ayurveda Tattva Sandipika by Kaviraj Ambikadutta Shastri, Chaukhamba publications, Varanasi, Edition: Reprint 2014, Part 2, Sushruta Chikitsasthan Chapter 1, Shloka no.8, Page no. 5.

[3] Chunekar K.C, Bhav Prakash Nighantu of Bhav Mishra with Hindi Commentary, Pande GSeditors. Guduchyadi varga. Revised Edition 2010. Varanasi. Chaukhambha Bharti Academy Publisher, P.no. 401

[4] Rijin Mohan et al. A bird eye view on vataja pandu. J Pharm Sci Innov. 2019;8(2):46-51. http://dx.doi.org/10.7897/22774572.082126 